\title{
A Thing of Great Beauty
}

\author{
Declan Moen \\ H Block 5, Long Kesh
}

Sonny Weir woke, as usual, in mid morning when he could no longer dismiss the noise of daily routine through the walls of his caravan. He eased back the grimy duvet and sat a while dangling his powerful legs. He ran his hands through his greasy, tangled hair, scuffed the days-old stubble on his face, and gave his piggish red eyes a tired rub before stepping gingerly onto the cracked lino, carefully avoiding the sticky remnants of last nights supper. As he padded over to switch off the TV, Sonny wheezed and gasped for air. An accident in a chemical plant had virtually destroyed his lungs and now, barely forty, he was medically unfit to work and had to make do with a small pension that he occasionally managed to supplement.

Always a driven type, Sonny had emigrated when young and travelled thousands of miles, changing from freckled youth to tanned adult along the way. Not one to settle, he had never thought of marrying or raising a family despite being slowed down by his polluted lungs. After years of travel, Sonny developed a crushing urge to return home, even now he couldn't fully comprehend his actions for what was there here? He secretly entertained notions of meeting someone nice to settle down with but his journey home had been extremely difficult, barriers were placed at every turn. Sonny lost all sense of direction in life and he mulled continuously over his youthful hunting grounds searching for memories but always coming away with the feeling that his life was increasingly shallow.

He had enjoyed fishing when younger and now took to the sport again with enthusiasm. After dressing, he loaded his small car with tackle. He drove, as always, at high speed the half mile or so to his favourite spot beside the old oak. Its reassuring bulk seemed to attract fish in great numbers. After casting Sonny nibbled at a swiss roll he had found lodged in his coat pocket, as he took his first bite his line swished tight and began to veer to the side. Sonny compensated for his lack of skill as an angler by using very strong line and this, coupled with the application of sheer brute force, ensured the fish was swiftly hauled ashore on its back. It was a reasonable size, eight to ten pounds, and was dispatched without ceremony with a sharp knock to the head before being tossed behind him where it lay on top of a discarded crisp bag, its glassy eyes staring accusingly at Sonny.

As a licence was required to fish this stretch and Sonny didn't possess one, he decided to drive at once to a local restaurant to see if they would buy the catch. He flung his gear into the back of the car. The fish was placed in the passenger seat. Engine whining noisily, Sonny sped off. He headed towards the new road, scattering water and gravel in his wake. Approaching the 
junction, Sonny rammed through the gears to prepare for the casual swing into the left lane. Just short of the turn, he was attracted to a glint of silver, amid the sudden confusion of sound and colour the stunned fish walloped and flipped inside the car causing Sonny to strike out with his hands to protect his face, the car shot across the road straight into a low stone wall. Never in his life had Sonny experienced such a brutal and ripping force, the sudden loss of momentum forced his breath outwards as he squeezed back into the comfort of his seat as though he was trying to curl up and hide before catapulting forward in a jerky motion, finally escaping the confines of the car as his smooth shiny forehead burst through the windscreen sending silver droplets of glass in a graceful shower over the clear blue bonnet. He continued on his powerful arc, twisting and gyrating, his head at a strange angle flopping back towards the vehicle as though tethered there, Sonny was finally deposited gently and noiselessly into a cool moist growth of green nettles where he lay quivering, his face skywards. His eyes, staring, bulged slightly outwards, his mouth made popping noises, like a child blowing bubbles as he fought to breathe. An excited crowd had witnessed the event and huddled closer, craning to see. Among the low murmur of comment they tut tutted and shook their heads until the ambulance finally arrived. 'Phew, this un's a big un and no mistake!' said an attendant as Sonny was carried, face up, through the crowd as though he was being paraded for their approval. His eyes, wide in fright, were glassy and hard, his mouth, pursed in surprise, was still. Nearby, two old men stood and watched as the ambulance drove away. 'I tell you' said one 'he was that far from hitting the youngster when he crossed the road' holding his hands two feet apart to emphasise the distance involved. 